\title{
REVEALED COMPARATIVE ADVANTAGE INDEX: AN ANALYSIS OF EXPORT TRADE IN THE AUSTRIAN DISTRICT OF BURGENLAND
}

\section{Doris Granabetter}

M.A., MA, Ph.D Student, International Joint Cross-Border PhD

Programme in International Economic Relations and Management, University of Applied Sciences Burgenland (UAS), Eisenstadt, Austria/University of Sopron, Hungary; doris.granabetter@aon.at

Article info

Paper category: Review paper Received: $19 \cdot 5 \cdot 2016$. Accepted: 28.6.2016.

JEL classification: B 41, C 82, E 23, F 14 


\begin{abstract}
The Austrian District of Burgenland is located in the eastern part of the country. In the last decade, the region has benefited from different subsidy programs from the European Union. The aim of this paper is to analyze and evaluate the export competitiveness of Burgenland in relation to the foreign trade of Austria as a whole from 2010 to 2014, which is the period showing the highest increase in exports since the Iron Curtain fell. The Revealed Comparative Advantage index (RCA) was used to determine the development of the region's exports. The RCA index is used in international economics for calculating the relative advantage or disadvantage of a certain country in a certain class of goods or services. The findings show that Burgenland has important exports of agricultural products and that economic relationships with neighbouring countries are deepening. This study is an important contribution towards demonstrating the development of former Objective 1 area countries in the European Union.
\end{abstract}

\title{
Keywords:
}

Export competitiveness, Burgenland, Revealed comparative advantage 


\section{INTRODUCTION}

The aim of this paper is to analyze and evaluate the export competitiveness of Burgenland compared to the foreign trade of Austria as a whole from 2010 to 2014 . This period was chosen because exports showed record increases over this time compared to any other period since the Iron Curtain fell. The final year of data used was 2014 because the data for 2015 were not available at the start of the study. The chosen metric for the analysis is the Revealed Comparative Advantage (RCA), derived for 97 product categories and 20 countries.

Burgenland is located in the eastern part of Austria. In the last decade, the region has benefited from different subsidy programs from the European Union proclaims the Regional management Burgenland on his website (As of June 12, 2016, http:// www.phasing-out.at) ${ }^{1}$. Although this has contributed to increasing exports from the district, Burgenland still has the smallest export share of all Austrian districts (Figure 1.). In general, foreign trade has risen from 2010 to 2014 in all districts.

Figure 1.: Export rates of Austria and its districts

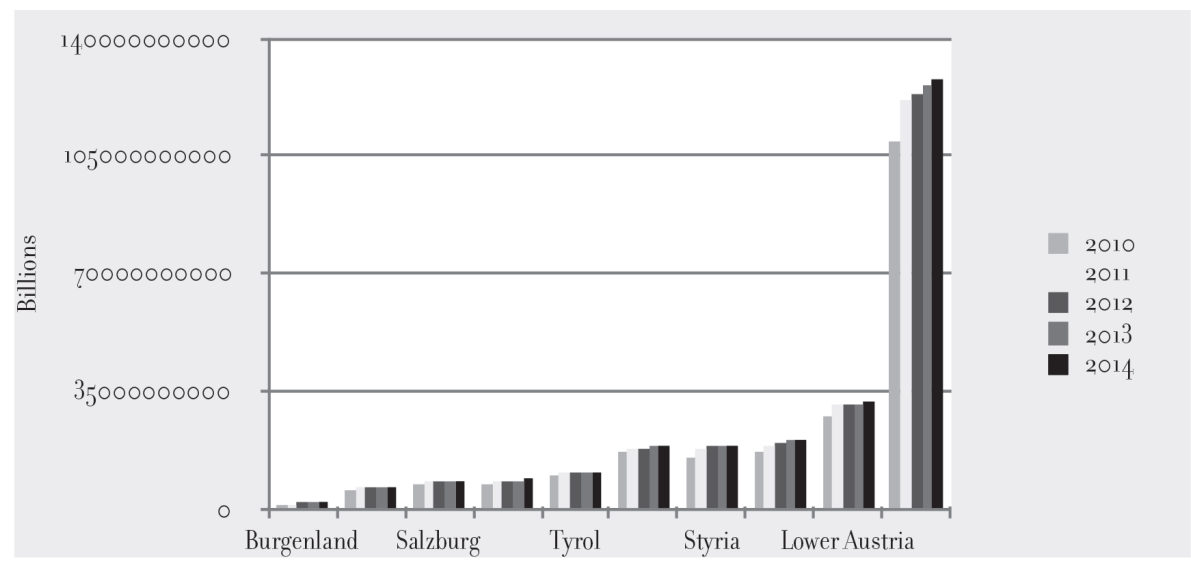

Source: WKO Statistics

Relation Value Exports from 2010 - 2014

Historically, the region is characterized by agriculture, although the area of land in agricultural use has declined slightly through recent decades. In 1990 there were 325,000 ha of agricultural land, 8.8 percent more than today. ${ }^{2}$ According to Statistik Austria, in 2010 there were 288,000 ha of agricultural land, a historical low. Four years later the agricultural area was $299,000 \mathrm{ha}$, an increase of 3.9 percent. $^{3}$

1 Granabetter, "Export between the Poles Globalisation and Regionalisation-using the Case of the Austrian District Burgenland", 1-2.

2 "Der grüne Bericht 2009", Amt der burgenländischen Landesregierung, 11.

3 "Statistik der Landwirtschaft", Statistik Austria, 94. 
Goods "Made in Burgenland" are enjoying increasing popularity abroad, including agricultural products. In 2010, Burgenland reported exports amounting to 1.5 billion euros and by 2014, this had risen to 2 billion euros, an increase of one third 4 . Nearly 5 percent of the 17,000 companies of the region are engaged in exports, which is considerably below the Austrian average of 10 percent of entrepreneurs engaged in operations abroad 5 .

Exports by manufacturing companies of the regional economy (without merchandise sales) rose to a record level in 2014, of around 1.3 billion euros. But in comparison with other districts the export ratio of 35.8 percent is the weakest of all Austrian provinces.

In Burgenland the major share of exports comes from industry (1 billion euros). The businesses of this division have increased their export volume again after a slump in 2009 .

Table 1.: Exports from Burgenland, showing the value of the top 10 ranking product groups

\begin{tabular}{|l|r|r|r|r|r|}
\hline \multicolumn{1}{|c|}{ Product group } & $\mathbf{2 0 1 0}$ & $\mathbf{2 0 1 1}$ & $\mathbf{2 0 1 2}$ & $\mathbf{2 0 1 3}$ & $\mathbf{2 0 1 4}$ \\
\hline Electronics & 508.0 & 352.2 & 529.8 & 516.0 & 577.6 \\
Plastics & 126.5 & 184.2 & 187.1 & 183.0 & 152.8 \\
Machinery, technical equipment & 78.5 & 134.6 & 130.5 & 130.6 & 131.6 \\
Synthetic fibres & 76.6 & 3.9 & 4.4 & 106.7 & 106.2 \\
Cereals & 30.2 & 33.7 & 36.2 & 83.0 & 80.2 \\
Waste from the food industry & 51.1 & 22.2 & 25.2 & 66.1 & 74.2 \\
Automobiles and parts thereof & 64.7 & 77.2 & 92.5 & 70.5 & 74.0 \\
Wood and wood products & 60.1 & 53.8 & 54.8 & 53.2 & 55.4 \\
Books and newspapers & 73.6 & 50.9 & 55.2 & 64.2 & 5.1 \\
Glothing & 40.9 & 187.2 & 186.2 & 58.2 & 50.7 \\
\hline
\end{tabular}

Source: Statistik Austria, figures in million Euros

The most important product groups for export are electronics, plastics, machinery and technical equipment (Table 1.). In 2014, cereals, waste from the food industry and wood products, all of which are attributable in a broader sense to agriculture, were ranked fifth, sixth and eighth in the top 10 respectively. The largest increase in the period from 2010 to 2014 was shown by the product group cereals with an increase of 165.35 per cent.

In the manufacturing sector of crafts and trades, butchers together with the food and beverage industry have the highest export ratios (34.3 percent). Overall the exports from this division are worth 103 million euros annually.

4. "Exporte und Importe burgenländischer Unternehmen", Wirtschaftskammer Burgenland.

5 Anzinger and Müllner-Stefenelli, "Analyze des Wiener Außenhandels". 
Table 2.: The top 20 export destinations OF Burgenland's economy by value

\begin{tabular}{|c|c|c|c|c|c|}
\hline $\begin{array}{l}\text { Export } \\
\text { country }\end{array}$ & 2010 & 2011 & 2012 & 2013 & 2014 \\
\hline Belgium & 19.2 & 16.9 & 16.9 & 16.9 & 19.5 \\
\hline China & 48.1 & 63.4 & 63.6 & 59.5 & 68.7 \\
\hline Croatia & $9 \cdot 5$ & 8.3 & 7.0 & 9.0 & 13.2 \\
\hline $\begin{array}{l}\text { Czech } \\
\text { Republic }\end{array}$ & 40.2 & 41.1 & $4^{3.9}$ & 44.7 & 42.3 \\
\hline France & 61.0 & 59.8 & 68.7 & 64.0 & $5^{8.9}$ \\
\hline Germany & $55^{3.8}$ & 599.0 & 626.4 & 610.6 & $57^{3} .5$ \\
\hline Great Britain & $59 \cdot 4$ & $59 \cdot 6$ & 60.5 & 64.8 & 67.3 \\
\hline Hungary & $124 \cdot 4$ & $175 \cdot 7$ & 188.4 & 241.6 & 297.0 \\
\hline Italy & $7^{8.3}$ & 74.9 & 77.2 & 90.6 & 89.2 \\
\hline Netherlands & 42.8 & $38 . \circ$ & 36.9 & 32.8 & 28.9 \\
\hline Poland & 54.2 & 49.2 & 44.5 & 56.0 & $54 \cdot 4$ \\
\hline Romania & 54.0 & 32.9 & 27.2 & 28.8 & 38.3 \\
\hline Russia & 23.3 & 21.7 & 33.2 & 55.5 & 42.4 \\
\hline Slovakia & 23.5 & 3०.3 & 31.0 & 37.5 & $37 \cdot 4$ \\
\hline Slovenia & 34.6 & 38.8 & $47 \cdot 4$ & 61.4 & $64 \cdot 4$ \\
\hline Spain & 23.3 & 35.4 & 35.1 & 42.5 & 44.5 \\
\hline Sweden & 16.1 & 17.6 & 23.8 & 3o.8 & $45 \cdot 1$ \\
\hline Switzerland & 33.6 & 40.4 & $45 \cdot 9$ & 75.1 & 70.5 \\
\hline Turkey & 27.5 & 29.9 & 26.1 & 25.1 & 24.9 \\
\hline United States & $27 \cdot 4$ & 34.4 & 55.1 & 57.8 & 52.2 \\
\hline
\end{tabular}

Source: Statistik Austria, figures in million Euros, not rounded

In 2014, the most important export destinations for Burgenland's economy were Germany, Hungary, Italy, Switzerland and China (Table 2).

- What does this mean in comparison to Austrian Exports in general?

- What groups benefit from an advantage and to what extent?

- Which sectors are declining? Which are booming?

- Which countries are promising markets for Burgenland's economy?

According to the United Nations Conference on Trade and Development (UNC$\mathrm{TAD}$ ) and the World Trade Organization (WTO), world merchandise exports rose moderately by 0.6 percent in 2014, reaching 19 trillion US Dollars ${ }^{6}$.

Austria's merchandise exports increased from 152,560 million US dollars in the year 2010 to $178,24,8$ million in 2014 , while services exports rose from 52,739 million US dollars in the year 2010 to 67,311 million in $2014 .{ }^{7}$

6 UNCTAD, "In 2014, world merchandise exports grew by 0.6 percent, while trade in services recorded a 4.2 percent global increase".

7 UNCTADSTAT, General Profile: Austria, General Information for 2014. http://unctadstat.unctad.org/ CountryProfile/GeneralProfile/en-GB/o4,o/index.html. 
Although Austrian exports increased in absolute numbers from 2010 to 2014, its market share in world exports decreased by 15.72 percent over the five year period. ${ }^{8}$

The objectives of this paper are to analyze the importance of Burgenland's merchandise exports in comparison to Austrian merchandise exports.

In the next section the theory around export performance research is outlined, with particular focus on the RCA index. The methodology used and the hypotheses tested are introduced in section three. The results section shows the calculated figures for countries with an RCA index higher than 1 , the ranking of the top 20 export product groups and the classes with the largest growth and the strongest decline.

\section{THEORETICAL FRAMEWORKAND REVIEW OF SELECTED LITERATURE}

Export performance research has proliferated in recent decades. The field of inquiry is characterized by a diversity of conceptual, methodological, and empirical approaches that inhibit the development of clear conclusions regarding the determinants of export performance. ${ }^{9}$

In the development and evolution of international trade theory, comparative advantage has always been a core concept. Since Ricardo's (1817) classic model of comparative advantage (CA) in trade was put forward, the theory of comparative advantage has been gathered to form a theory system. An approach of comparative advantage calculation through almost two centuries' development. The most widely used application has been proposed after the Revealed Comparative Advantage (RCA) and its modification put forward by Balassa (1965). ${ }^{10}$

Comparative advantage analysis is a useful tool in economics that can be used to compare the relative costs of production and identify sectors and markets that have the greatest likelihood of success. Balassa Index is widely used in the field to measure country-sector Revealed Comparative Advantage.

Examples publishes in the last year are the "Empirical Analysis of Agricultural Exports Competitive of Henan Province" (Proceedings of 2015 2nd International Conference on Industrial Economics System and Industrial Security Engineering, 187-193, December 2015), "Determinants of revealed comparative advantages: The case of cheese trade in the European Union" (published in Acta Alimentaria-An International Journal of Food Science by Jeremias Balogh and Attila Jámbor) or the publication "Uganda's Revealed Comparative Advantage in COMESA" by Miriam Katunze and Annette Kuteesa.

8 Republik Österreich Parlament, Warnmechanismusbericht 2016, 4.

9 Shaoming and Stan, "The determinants of export performance: a review of the empirical literature between 1987 and 1997", $333-356$.

$10 \mathrm{Jia}, \mathrm{Wu}$ and Liu. "The Evolution of Measurement Methods of Comparative Advantage and New Trends in Intra-Product International Specialization", 82. 
Two different approaches are normally used to assess comparative advantage: the Domestic Resource Cost (DRC) and the Revealed Comparative Advantage (RCA) methods. ${ }^{11}$

In comparison to RCA the DRC index has a big disadvantage. The DRC approach requires data on production costs which may be hard to obtain. In contrast, the data required for the calculation of the RCA index are normally available in publicly available statistics. Another potential advantage of this method is that it is more descriptive, but it does have less predictive potential than the DRC approach.

Another variation of the RCA index is the model suggested by Donges and Rie$\operatorname{del}^{12}$ where both export and import is included. The RCA index suggested by Bowen ${ }^{\mathbf{3}}$ considers the production of a particular country and net trade (i.e. production minus consumption). The RCA indices suggested by Vollrath ${ }^{\mathbf{1 4}}$ measure exports and imports in relation to the rest of the world ${ }^{15}$.

On the other hand Leromain and Orefice criticize this method because it mixes up all the factors influencing trade flows. ${ }^{16}$

\section{METHODOLOGY}

The RCA index was used to determine the most important destinations and product groups for the region's export trade. It is used in international economics to calculate the relative advantage or disadvantage of a certain country in a certain class of goods or services.

The study used data for 99 product groups and 197 countries which are compiled by Statistik Austria and the Economic Chamber of Austria. To improve the readability of the paper the focus is on the top 20 product groups and countries with an RCA index above 1. Data for the period 2010 to 2014 were used because the increase in Burgenland's exports over this time was the highest since the fall of the Iron Curtain. The relevant figures for 2015 were not available at the time of the analysis and are not reported here.

11 Hishamunda, Junning and PingSung. "Assessment of comparative advantage in aquaculture: framework and application on selected species in developing countries".

12 Donges and Riedel. "The expansion of manufactured exports in developing countries: An empirical assessment of supply and demand issues", $5^{8-87}$.

13 Bowen. "On the theoretical interpretation of indices of trade intensity and revealed comparative advantage", $464-472$.

14 Vollrath. "A theoretical evaluation of alternative trade intensity measures of revealed comparative advantage." 265 -280.

15 Hishamunda, Junning and PingSung. Assessment of comparative advantage in aquaculture: framework and application on selected species in developing countries, 69.

16 Leromain and Orefice, "New Revealed Comparative Advantage Index: Dataset and Empirical Distribution," 50. 
Usually, the index is used to give results for a specific country. This paper applies it to a district and analyzes the exports of that part of the country as compared with the state's exports in general. The idea is to consider the relationship between changes in the export destinations and product categories of a district to those of the next largest geographical unit, the nation.

RCA most commonly refers to an index introduced by Béla Balassa $(1965)^{17}$.

$\mathrm{RCA}=\left(\mathrm{E}_{\mathrm{ij}} / \mathrm{E}_{\mathrm{it}}\right) /\left(\mathrm{E}_{\mathrm{nj}} / \mathrm{E}_{\mathrm{nt}}\right)$

where $\mathrm{E}$ is exports, ${ }_{i}$ is the country index, ${ }_{n}$ is the set of countries, ${ }_{j}$ is the commodity index and is the set of commodities.

That is, the RCA is equal to the proportion of the country's exports that are of the class under consideration $\left(\mathrm{E}_{\mathrm{ij}} / \mathrm{E}_{\mathrm{it}}\right.$ ) divided by the proportion of world exports that are of that class $\left(\mathrm{E}_{\mathrm{nj}} / \mathrm{E}_{\mathrm{nt}}\right)$. In this study the figures for a federal province in Austria, i.e. Burgenland, were compared with Austria's exports as a whole in order to assess the development of Burgenland's exports relative to Austrian market share.

A comparative advantage is "revealed" if RCA $>1$. If RCA is less than unity, the country is said to have a comparative disadvantage in the commodity or industry.

The RCA index is used to analyse different sectors, particularly in agriculture, e.g. Aquaculture ${ }^{18}$ and countries, e.g. China, India ${ }^{19}$ and Turkey ${ }^{20}$. The weighting of exports from different product groups like agricultural products are examined with respect to the economies of the relevant export destinations. For a secondary data analysis, the company database of the Burgenland Economic Chamber is used.

The following hypotheses were tested:

$\mathrm{H}$ 1: Economic relations with neighboring countries, in particular Hungary, have continued to develop more than 10 years after the fall of the iron curtain.

$\mathrm{H}$ 2: The share of agricultural products in export has declined in Burgenland compared to Austria as a whole in favor of technological products.

\section{STUDY RESULTS}

The calculations of the RCA index were carried out by product group and country. Considering the export destinations, it is particularly striking that Hungary is an important business partner.

This is perhaps unsurprising considering its geographical location - Burgenland shares a border with Hungary (Table 3.).

$\mathrm{H}$ 1: Economic relations with neighboring countries, in particular Hungary,

17 Balassa, Trade Liberalisation and Revealed Comparative Advantage, 99-123.

18 Hishamunda, JunNing and PingSung, Assessment of comparative advantage in aquaculture: framework and application on selected species in developing countries, $5_{2}^{28}$.

19 Batra and Khan. Revealed Comparative Advantage: An Analysis for India and China, 5.

20 Serin and Abdulkadir. Revealed Comparative Advantage and Competitiveness: A Case Study for Turkey towards the EU, 25-41. 
have continued to develop more than 10 years after the fall of the iron curtain. The hypothesis is thus confirmed.

The relatively high value of exports to Sweden is remarkable. This highlights the importance of comparing the RCA values with the business directory of the Economic Chamber. The particularly high value for Burgenland concerning Sweden can probably be associated with a parent company in this country.

Table 3.: RCA indices for Burgenland compared to other Countries 2010-2014

\begin{tabular}{|l|r|r|r|r|r|}
\hline \multicolumn{1}{|c|}{ Country } & $\mathbf{2 0 1 0}$ & $\mathbf{2 0 1 1}$ & $\mathbf{2 0 1 2}$ & $\mathbf{2 0 1 3}$ & $\mathbf{2 0 1 4}$ \\
\hline Hungary & 2.6 & 3.3 & 3.5 & 4.0 & 4.4 \\
Sweden & 0.9 & 0.9 & 1.2 & 1.4 & 2.1 \\
Slovakia & 1.0 & 1.1 & 1.2 & 1.5 & 1.5 \\
Spain & 0.8 & 1.3 & 1.3 & 1.3 & 1.3 \\
Turkey & 1.8 & 1.7 & 1.4 & 1.2 & 1.3 \\
Romania & 2.2 & 1.2 & 0.9 & 1.0 & 1.3 \\
China & 1.2 & 1.5 & 1.4 & 1.2 & 1.3 \\
Great Britain & 1.2 & 1.2 & 1.2 & 1.1 & 1.1 \\
\hline
\end{tabular}

Source: Author's calculation/Statistik Austria, not rounded

Other countries with a benchmark RCA $>1$ are Slovakia, another market on the doorstep of Burgenland, Spain, Turkey, Romania, China and Great Britain. According to UNCTAD and WTO, between 2009 and 2010 the highest growth rates in the world were registered by the least developed countries (13.5 percent), followed by developing Asia (9.5 percent) and America (8.1 percent). ${ }^{21}$

For Burgenland, trade to only one Asian market, China, is significant. The other thriving markets are members of the European Union and related nations. There is a mutually beneficial relationship between Burgenland's economy and the economies of adjacent countries. Considering the RCA indices of different product groups, the most important categories in 2014, were plaiting (included in this category are bamboo and reed), cereals and oil seeds.

Table 4.: RCA indices for the top 20 product groups of Burgenland 2010-2014

\begin{tabular}{|l|r|r|r|r|r|}
\hline $\begin{array}{c}\text { Product group - } \\
\text { Ranked by 2014 values }\end{array}$ & 2010 & 2011 & 2012 & 2013 & $\mathbf{2 0 1 4}$ \\
\hline Plaiting & 37.1 & 1.1 & 0.8 & 10.2 & 20.9 \\
Cereals & 8.0 & 6.2 & 6.9 & 13.7 & 12.6 \\
Oil seeds, oleaginous fruits, & 6.4 & 4.3 & 9.1 & 15.5 & 11.9 \\
seeds, straw & 5.2 & 8.4 & 12.1 & 12.0 & 10.8 \\
Silk & 12.2 & 4.2 & 4.3 & 11.2 & 9.5 \\
Books, newspapers & & & & & \\
\hline
\end{tabular}

21 UNCTAD, "In 2014, world merchandise exports grew by 0.6 percent, while trade in services recorded a 4.2 percent global increase". 


\begin{tabular}{|c|c|c|c|c|c|}
\hline $\begin{array}{c}\text { Product group - } \\
\text { Ranked by } 2014 \text { values }\end{array}$ & 2010 & 2011 & 2012 & 2013 & 2014 \\
\hline Staple fibres & 6.6 & 1.9 & 2.2 & 7.9 & 7.8 \\
\hline $\begin{array}{l}\text { Waste from the food } \\
\text { industry, food }\end{array}$ & 11.9 & 4.0 & 3.5 & 7.3 & 7.5 \\
\hline $\begin{array}{l}\text { Plants and floricultural } \\
\text { products }\end{array}$ & 9.8 & 2.1 & 1.7 & 7.0 & 7.0 \\
\hline $\begin{array}{l}\text { Fur skins and artificial fur; } \\
\text { manufactures thereof }\end{array}$ & 5.1 & 3.0 & $4 \cdot 4$ & 6.1 & 6.4 \\
\hline Textile articles, rags & 6.9 & 1.7 & 1.8 & 5.3 & 5.0 \\
\hline $\begin{array}{l}\text { Clothing and Accessories, } \\
\text { except knitted/crocheted }\end{array}$ & 3.9 & 6.2 & 6.0 & 4.6 & 3.9 \\
\hline Various products & 3.1 & 2.3 & 1.3 & 2.9 & 3.5 \\
\hline $\begin{array}{l}\text { Cocoa and cocoa } \\
\text { preparations }\end{array}$ & 2.5 & 3.3 & 2.9 & $2 \cdot 7$ & 2.8 \\
\hline Electronic machines & 3.0 & 2.2 & 3.0 & 2.5 & 2.8 \\
\hline $\begin{array}{l}\text { Clothing knitted or } \\
\text { crocheted }\end{array}$ & 2.0 & 5.2 & 4.5 & 2.5 & 2.4 \\
\hline Various food preparations & 1.3 & 0.8 & 0.9 & 1.4 & 2.2 \\
\hline Rubber and articles thereof & 1.8 & 0.9 & 1.1 & 2.4 & 2.1 \\
\hline $\begin{array}{l}\text { Leather, saddlery, travel } \\
\text { goods, handbags }\end{array}$ & 1.2 & 2.9 & 3.1 & 2.5 & 2.0 \\
\hline $\begin{array}{l}\text { Preparations of cereals, } \\
\text { flour, bakery products }\end{array}$ & 2.6 & 1.3 & 1.2 & 2.0 & 2.0 \\
\hline Coffee, tea, spices & 1.4 & 0.4 & 0.5 & 2.3 & 2.0 \\
\hline
\end{tabular}

Source: Author's calculation/Statistik Austria, not rounded

The observations show large fluctuations over the years. The RCA index for the product group plaiting for example ranges from 37.1 in the year 2010 to 0.8 in the year 2012. Different product groups have different ranges of variation over the years. Plaiting shows the largest range. Cocoa and cocoa preparations are relatively constant, ranging from 2.5 in the year 2010 to 3.3 in the following year (Table 4).

Evaluating the RCA index of the product groups in different sectors in the observed period shows that fur skins and artificial fur has among the largest growth in Burgenland as do the category "various products" and products in the areas of food preparation and preparation of vegetables, fruit and plants (Figure 2). "Various products" as defined here include in the case of Burgenland the product groups pencils and zippers. Two enterprises which manufacture these products have establishments in Burgenland. An upward trend is also seen in the product group pearls, precious or semiprecious stones and coins. Important in the list are furthermore products of the textile industry, like silk, textile articles, clothing and accessories, clothing, leather, and furthermore various food preparations and preparations of cereals, flour and bakery products, concerning the food industry. 
Significant factors also newspapers and magazines. No product groups show only an upward trend. Over the years' variations are recorded.

$\mathrm{H}$ 2: The share of agricultural products in export has declined in Burgenland compared to Austria as a whole in favor of technological products.

Comparing the absolute numbers of the 97 product groups which are given in the product catalogue of Statistics Austria, the export share of agrarian products rose from 20 to 25 percent in the years 2010 to 2014 . This calculation and also the RCA index show that, contrary to $\mathrm{H}_{2}$, the share of agricultural products increases. $\mathrm{H}_{2}$ is false. Indeed, the top three product groups in 2014 - plaiting, cereals and oil seeds are all of agrarian origin.

This means that Burgenland's economy has a high relative share in these groups compared to the wider Austria's exports. Staple fibres and electronic machines, technological products, were the sixth and fourteenth most important product groups in 2014 .

Figure 2.: Product groups with the largest growth IN BURGENLAND, 2010-2014

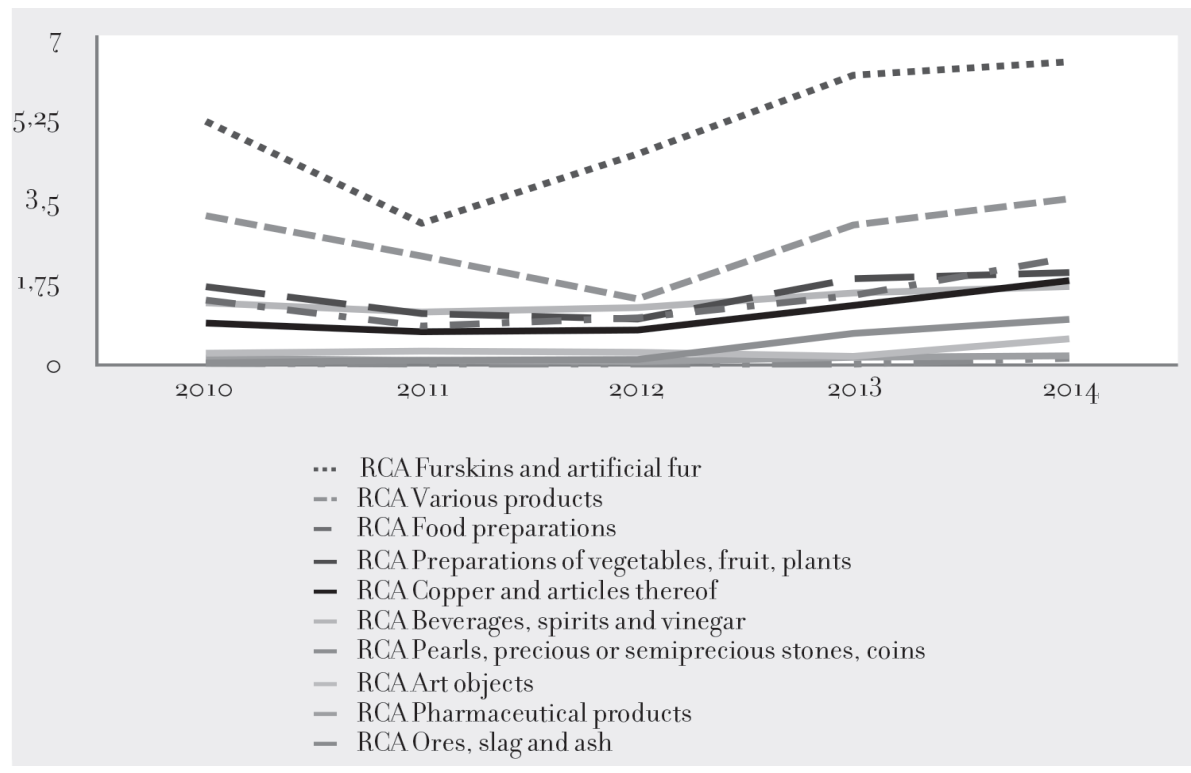

Source: Author's calculation

From 2010 to 2014, the product groups fur skins and various products showed all in all a great upward trend. Moderate growth was in food preparations, copper and articles thereof, beverages, spirits and vinegar. The fluctuations of the product groups pearls, precious or semiprecious stones, coins, art objects, pharmaceutical products and ores, slag and ash are moving at a low level.

Looking at the products that can be defined in the broadest sense to be agricultural, these product groups are a sustainable base for the further development of 
trade balance. The export share of agrarian products in Burgenland was 20 percent in 2010 and 23 percent in the year 2014. Burgenland is an agrarian region with a growing export share.

This is also reflected in the calculations of the RCA index. In the product groups which have recorded growth during the observation period are a disproportionate number of agricultural origin: Food preparations, preparations of vegetables, fruit, plants, beverage, spirits and vinegar.

Figure 3.: Product groups with STRONGEST declines IN BURGENLAND, 2010-2014

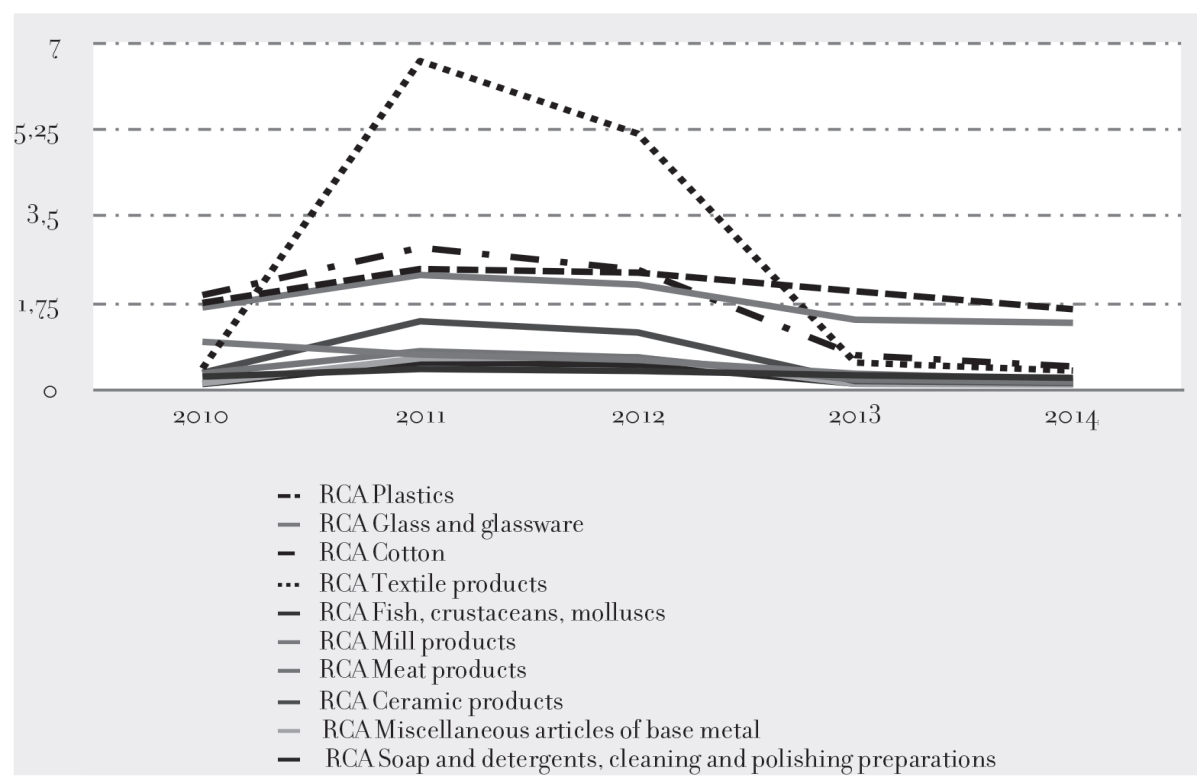

Source: Author's calculation

The RCA index shows a sharp decline in the areas of textile products and cotton in the year 2013 after the highest increase in 2011. Some textile companies have withdrawn their production from Burgenland, the production moved to other Austrian regions or even other countries.

Moderate declines in plastics and mill products can also be seen during the entire observation period. As with the increasing products, the RCA index for declining products also shows strong variations (Figure 3.).

From 2010 to 2014 the product groups ceramic products, fish, crustaceans, mollusks, meat products, miscellaneous articles of base metal and soap and detergents, cleaning and polishing preparations show declines at a low level. 


\section{DISCUSSION}

Observation by RCA index shows that Burgenland has - especially in the product categories for which it is due to the geographical and climatic conditions suitable - a great advantage over the Austrian exports, for example reed, cereals, oil seeds, straw. Burgenland is the region with the most hours of sunshine in Austria and good production conditions for agriculture, especially compared to the higher situated areas in the western part of Austria.

To check the significance of the results, it is necessary to compare the data with the business directory of the Economic Chamber of Burgenland. A comparison of the results shows the global players and hidden champions of Burgenland's economy, e.g. in the agrarian sector there are important companies like Felix Austria, Mars, Pöttelsdorfer Edelpute, Rebschule Tschida, Schärf coffeeshop, Pioneer and various wineries and in the technical sector there are other important companies like Trevision, Seal Maker, Vossen, Lenzing, Isosport, Medtrust, YKK, Hella, Brevillier-Urban and Boxmark Leather.

The listed companies have a high export ratio and have established contact with the Foreign Trade Department of Commerce or have applied for export papers. A comparison of the secondary data from the corporate directory and business partner database of Commerce Burgenland confirms the analysis.

EU Cohesion Policy sets a framework to reduce differences between regions. Burgenland, which is the focus of this study, is a federal state of Austria and had a special status as an Objective 1 area. The Vienna Institute for International Economic Studies (wiiw) analyzed foreign trade flows for several European countries. "For regional policy strategies to be effective, and for an efficient use of the available funds, it is crucial to analyze in detail the assets each region is endowed with, the technologies available, and the business connections among different regions. Against this background, the study evaluated EU regions' international competitiveness on the basis of their Revealed Comparative Advantage (RCA), complemented by additional trade indicators such as trade balances or export specialization and a series of regional and sectoral characteristics such as skill supply, R\&D and patents. For this study, wiiw developed a model to consistently estimate foreign trade flows (export and imports) at the NUTS-2 regional level"22.

But isn't the RCA index a superficial measure of export trade? This method does not measure the circumstances of the market, or show economic and political implications. One alternative is Constant Market Share-Analysis which considers the effects of the world market, of varied patterns, of regional structure and competition.

Leromain and Oreficice introduced another method of analysis, a new economic-based measure for Ricardian RCA. In their opinion, the new, modified measure showed better statistical properties than the Balassa index.. ${ }^{23}$ They extended the

22 Römisch, "Trade competitiveness of Austrian and neighbouring regions", 6.

23 Leromain and Orefice, "New Revealed Comparative Advantage Index: Dataset and Empirical Distribution". 
measure in two main directions, using a higher level of sector disaggregation and a larger set of partner countries.

The absolute level of exports indicates nothing about the extent to which a country is dependent on the international division of labor. In order to obtain such an assessment, exports must be considered in relation to gross domestic product. For deeper analysis multiple parameters must be included. The RCA index is useful for an initial assessment, and is applicable for countries, product groups, and time series. A forecast generated by the present data is problematic, because the data for product groups and the values of export share to foreign countries have in most cases a large inter-annual variation. It is worth paying attention to the development of countries with an RCA index less than one, like Croatia. This market has an increasing importance for Burgenland's economy, and its index has risen from 0.6 in 2010 to 0.7 in 2014.

In the opinion of Brakman one of the major new developments in the character of international trade over the last 25 years has been the increased fragmentation of the production process.

Many traded products are produced in international supply chains. For international trade analyzes this is an important development as gross exports are painting an incomplete picture of the nature of international trade. Brakman analyzed Revealed Comparative Advantage in the field of gross versus value added trade flows. With respect to comparative advantage the differences between the two types of data are often illustrated by means of examples using a single sector. In the Ricardian theory of comparative advantage, however, the position of a commodity versus all other commodities in a country determines whether or not a sector has a comparative (dis)advantage. His conclusion: RCA calculated with value added data is the most useful ${ }^{24}$.

\section{CONCLUSION}

The RCA index was selected for this study to determine the most important destinations for the region's trade. In international economics RCA is used to obtain results for a specific country or an individual business. In this study officially-available data was used to calculate the RCA index for a specific district relative to the entire state, with reliable results.

Results show that the RCA index can be used to show the value of exports from a federal state to particular nations. The analysis is able to evaluate the export share of a district for different product groups and export destinations.

The upward trend in RCA in recent years is an important signal for the whole economy. Exports create growth and jobs. Internationalization is therefore an important component of our business strategy to protect jobs and prosperity in the region. Nearly 5 percent of the 17,000 companies of the region are engaged in exports,

24. Brakman and Van Marrewijk. A closer look at Revealed Comparative Advantage: Gross-versus value added trade flows. 
half of the Austrian average. The results of this study imply that the number of exporters in Burgenland will increase in the near future.

The results of this study indicate that there are many economically interesting product groups in the region, this situation is therefore little or very little known to the public.

Burgenland is well known for wine around the world. But this study also shows that there are a lot of hidden champions in agriculture, commerce. Industries flourish in obscurity, like the production of reeds, belonging to the category plaiting, cereals, oil seeds or magazines and newspapers. Wine only plays a minor part despite its higher profile.

A look at the categories with significant growth potential indicates that the food sector, industrial production (car and medicine), and jewelry are promising markets.

In contrast, the textile industry in terms of exports is declining. The product groups textile, glass and glass ware, cotton, ceramic and mill products show also declining trends.

The economic relations to the neighboring country Hungary are intense. It would be of interest, if the upward tendency in exports can be associated with company settlements and cooperation in the neighboring country. An analysis of the exporting countries in connection with the product groups would be of great interest to recognize other trends and influences. The geographical location is probably the explanation for the good business relations to Hungary and Slovakia.

A comparison with the company database of the Economic Chamber of Burgenland suggests that the good economic relations to Sweden are founded by Swedish company branches in Burgenland.

Other recommendations for further research work: wherever scientific research is done, it expands the field of study so that the same topic can be further addressed from other perspectives, using other approaches or other benchmarks.

This study focuses on a limited time period and a particular region. In further work, it would be useful to examine longer time periods and expand the analysis to other Objective 1 areas in the European Union.

To understand the significance of a region in foreign markets, it is necessary to analyze the structure of activities in those markets. In addition to physical goods, service exports such as tourism, transport, telecommunication, insurance and construction play an increasingly important role.

The research objectives were achieved, but the results shown here only provide a measure of the importance of Burgenland merchandise exports. An additional study investigating the role of service exports would be of value to give an overview of Burgenland's export economy. 


\section{REFERENCES}

Anzinger, Barbara and Martin Müllner-Stefenelli, "Analyze des Wiener Außenhandels" (Vienna: Wirtschaftskammer Wien, 2012), internal survey

Balassa, Bella, Trade Liberalisation and Revealed Comparative Advantage, The Manchester School, 33 $(1965): 99^{-123}$

Batra, Amita and Zeba Khan, Revealed Comparative Advantage: An Analysis for India and China. Indian Council for Research on International Economic Relations NO. 168 (2005)

Bowen, Harry P., "On the theoretical interpretation of indices of trade intensity and revealed comparative advantage." Weltwirtschaftliches Archiv 119.3 (1983): 464-472

Brakman, Steven and Charles van Marrewijk, A Closer Look at Revealed Comparative Advantage: Grossversus Value Added Trade Flows (2015). CESifo Working Paper Series No. $5^{321}$

"Der grüne Bericht 2009", Amt der Burgenländischen Landesregierung, accessed April 21, 2016, http:// www.burgenland.at/fileadmin/user_upload/Downloads/Umwelt_und_Agrar/Agrar/Publikationen/ Gruener_Bericht/1870_Gruene_Bericht_2009_kl.pdf

Donges, Juergen B. and James Riedel. "The expansion of manufactured exports in developing countries: An empirical assessment of supply and demand issues." Weltwirtschaftiches Archiv 113.1 (1977): 58-87

"Exporte und Importe burgenländischer Unternehmen", Wirtschaftskammer Burgenland, accessed April 21, 2016, https://www.wko.at/Content.Node/ Interessenvertretung/Daten--Fakten--Zahlen/b/ Exporte-Importe-2010---2015.pdf

"Export- und Importquoten", Statistik Austria, WIFO, accessed March 15, 2016, http://wko.at/statistik/ Extranet/Langzeit/Lang-AHquoten.pdf

Granabetter, Doris M., "Export between the Poles Globalisation and Regionalisation-using the Case of the Austrian District Burgenland", Journal of EU Research in Business, 1-6, Vol. 2016, Article ID 9oo383, doi: $10.517^{1 / 2016.900383,2016}$

Hishamunda, Nathanael, Cai JunNing and Leung PingSung, Assessment of comparative advantage in aquaculture: framework and application on selected species in developing countries. FAO FISHERIES AND AQUACULTURE TECHNICAL PAPER, 528. ISBN 9789251064320, ISSN 2070-7010, 2009

Jia, Lijung, Maoguo Wu and Yixuan Liu, "The Evolution of Measurement Methods of Comparative Advantage and New Trends in Intra-Product International Specialization", SHU-UTS SILC Business School, Shanghai University, China, European Scientific Journal 12.7 (2016). accessed June 12, 2016, doi: 10.19044/esj.2016.v12n7p82, http://dx.doi.org/10.19044/esj.2016.v12n7p82

Leromain, Elsa, and Gianluca Orefice, "New Revealed Comparative Advantage Index: Dataset and Empirical Distribution", International Economics 139 (2014): 48-70

Republik Österreich Parlament, Warnmechanismusbericht 2016, Information des Budgetdienstes, 4, accessed May 6, 2016, https://www.parlament.gv.at/ZUSD/BUDGET/BD_-Warnmechanismusbericht_2016.pdf

Römisch, Roman, "Trade competitiveness of Austrian and neighbouring regions", wiiw monthly report Nr. 12/2015: 6 - 12, accessed June 6, 2016, http://wiiw.ac.at/monthl-report-no-12-2015-dlp-3758.pdf

Rübel, Gerhard, Außenwirtschaft (München: Oldenbourg Wissenschaftsverlag GmbH, München, 2013)

Serin, Vildan and Abdulkadir Civan. Revealed Comparative Advantage and Competitiveness: A Case Study for Turkey towards the EU. Journal of Economic and Social Research 10(2), (2008), 25-41 
"Statistik der Landwirtschaft", StatistikAustria, ISBN:978-3-902925-79-4, accessed April 21, 2016, http://www.statistik.at/web_de/statistiken/wirtschaft/land_und_forstwirtschaft/agrarstruktur flaechen_ertraege/arbeitskraefte/index.html

UNCTAD, "In 2014, world merchandise exports grew by o.6percent, while trade in services recorded a 4.2percent global increase", April 4, 2015, accessed May 16, 2016. http://unctad.org/en/pages/ newsdetails.aspx? OriginalVersionID $=975 \&$ Sitemap_xo020_Taxonomy=Statistics

UNCTADSTAT, General Profile: Austria, General Information for 2014, accessed May 5, 2016, http:// unctadstat.unctad.org/CountryProfile/GeneralProfile/en-GB/o4,o/index.html

Vollrath, Thomas L. "A theoretical evaluation of alternative trade intensity measures of revealed comparative a dvantage." Weltwirtschaftliches Archiv 127.2 (1991): 265-280

"Wirtschaftskammermitglieder nach Bundesländern", WKO Statistics, accessed March 9, 2015, http:// wko.at/statistik/jahrbuch/mg-km.pdf

Zou, Shaoming, and Simona Stan, "The determinants of export performance: a review of the empirical literature between 1987 and 1997", International Marketing Review, Vol. 15, Iss: 5 (1998) 
